\title{
18th Century Mexican Majolica Sherds from the George C. Davis Site (41CE19), Cherokee County, Texas
}

Timothy K. Perttula

Heritage Research Center, Stephen F. Austin State University

Follow this and additional works at: https://scholarworks.sfasu.edu/ita

Part of the American Material Culture Commons, Archaeological Anthropology Commons, Environmental Studies Commons, Other American Studies Commons, Other Arts and Humanities Commons, Other History of Art, Architecture, and Archaeology Commons, and the United States History Commons

Tell us how this article helped you.

This Article is brought to you for free and open access by the Center for Regional Heritage Research at SFA ScholarWorks. It has been accepted for inclusion in Index of Texas Archaeology: Open Access Gray Literature from the Lone Star State by an authorized editor of SFA ScholarWorks. For more information, please contact cdsscholarworks@sfasu.edu. 


\section{8th Century Mexican Majolica Sherds from the George C. Davis Site (41CE19), Cherokee County, Texas}

\section{Creative Commons License}

\section{(c) (1) \&}

This work is licensed under a Creative Commons Attribution-NonCommercial 4.0 International License 


\title{
$18^{\text {th }}$ Century Mexican Majolica Sherds from the George C. Davis Site (41CE19), Cherokee County, Texas
}

\author{
Timothy K. Perttula
}

\section{Introduction}

During the late $17^{\text {th }}$-early $18^{\text {th }}$ century, Spanish forces colonized the middle reaches of the Neches River and its tributaries when several missions were established for the Tejas and other Hasinai tribes in this locale: Mission San Francisco de los Tejas, 1690-1693, Mission El Santisimo de Nombre Maria (1690-1692), and Mission Nuestra Padre de San Francisco de Tejas (1716-1719, 1721-1730), otherwise known as Mission San Francisco de los Nechas (see Foster 1995; de la Teja 1999). These missions were established along the Hasinai Trace, later known as El Camino Real de los Tejas (see Weddle 2012). None of these missions have been located and identified in the many archaeological investigations that have been conducted in East Texas since the 1930s.

It has been known, however, since 1940 that early $18^{\text {th }}$ century artifacts have been found at the George C. Davis site (41CE19) on the Neches River at the crossing of the Camino Real (Figure 1). H. Perry Newell, the Works Progress Administration (WPA) excavator of the site, had noted in the published report on the 1939-1941 excavations at the George C. Davis site, that:

some pieces of Spanish pottery found near a spring in one of the ravines cutting the slope a few hundred yards southeast from the mound [Mound A]... The Spanish ware were examined by Arthur Woodward, Los Angeles County Museum...The Spanish ware was analyzed as follows: "The fragment of blue and white glazed ware is Mexican majolica, made at Puebla, Mexico, sometime between 1700-76 but more than likely it dates from 1720-1750" (Newell and Krieger 1949:12 and footnote 26).

This majolica from the George C. Davis site, about 20 sherds in total, has been recently relocated in the collections of the Texas Archeological Research Laboratory at The University of Texas at Austin (Figure 2a-c). The sherds are from early $18^{\text {th }}$ century (ca. 1720) Puebla Blue on White plates, a bowl, and a cup (see Fox and Ulrich 2008:80-81). Given the rarity of majolica on archaeological sites in East Texas outside of Spanish Colonial archaeological deposits, its presence at the George C. Davis site is especially intriguing given the fact that Mission San Francisco de Tejas/de los Nechas or Neches was built in this part of the Neches River valley in 1716, then rebuilt in 1721 (de la Teja 1999:194-195), and finally abandoned in 1730 .

\section{Context of the Majolica Sherds at the George C. Davis Site}

Newell and Krieger (1949:12 and footnote 26) indicated that the majolica sherds were found well south of Mound A at the George C. Davis site, on what would be the southern edge of the Neches River alluvial terrace the site is on (see Story 2000:Figure 1). More specific contextual information on the majolica finds was discovered in one of Newell's (1940) quarterly reports to the WPA on the progress of excavations at the site. Newell (1940:23-24) noted that:

A total of thirteen small fragments of a possible Spanish ware, with blue design, were found in certain sections excavated about six hundred feet southeast of the site proper [Mound A]. These sections were on the edge of a large gully and near two large springs. 


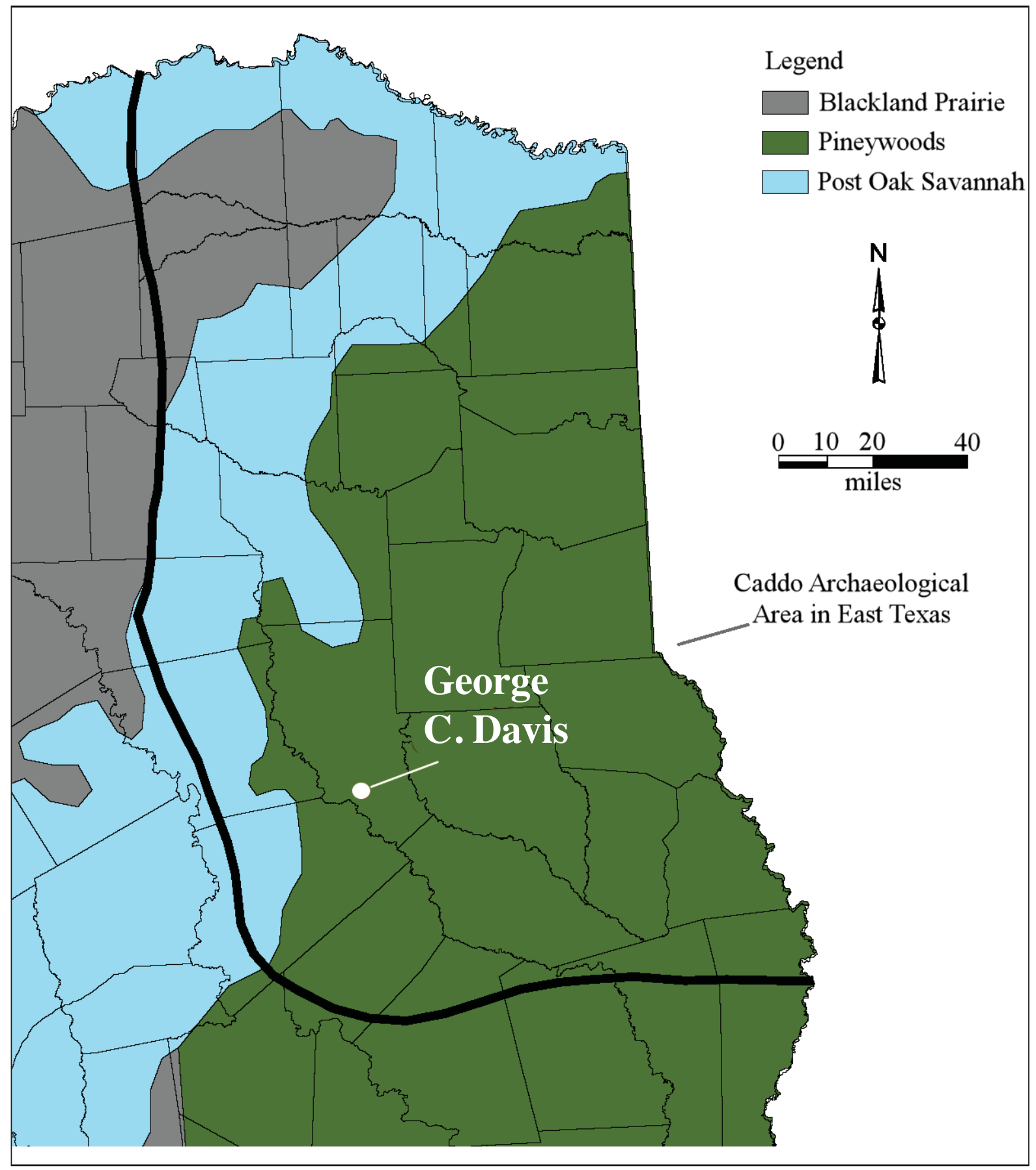

Figure 1. The location of the George C. Davis site in the Neches River valley in East Texas.

The Spanish pottery varied from 1 inch to 19 inches below surface. Indian pottery was found at about the same depth, and this pottery had decoration patterns similar to those found at the main site [Mound A].

Field specimen inventory records for the George C. Davis excavations indicate that the majolica sherds came from two separate $10 \times 10 \mathrm{ft}$. units (46L36 and 47L37) in a block of $1810 \mathrm{x} 10 \mathrm{ft}$. units excavated between March 7-12, 1940, in the southern part of the site (Figures 3 and 4a). Grid coordinate designations followed the designations used in the Mound A excavations (see Newell and Krieger 1949:Figure 4), except that the 10 x $10 \mathrm{ft}$. units were 45-48 sections south of the Mound A excavations. 

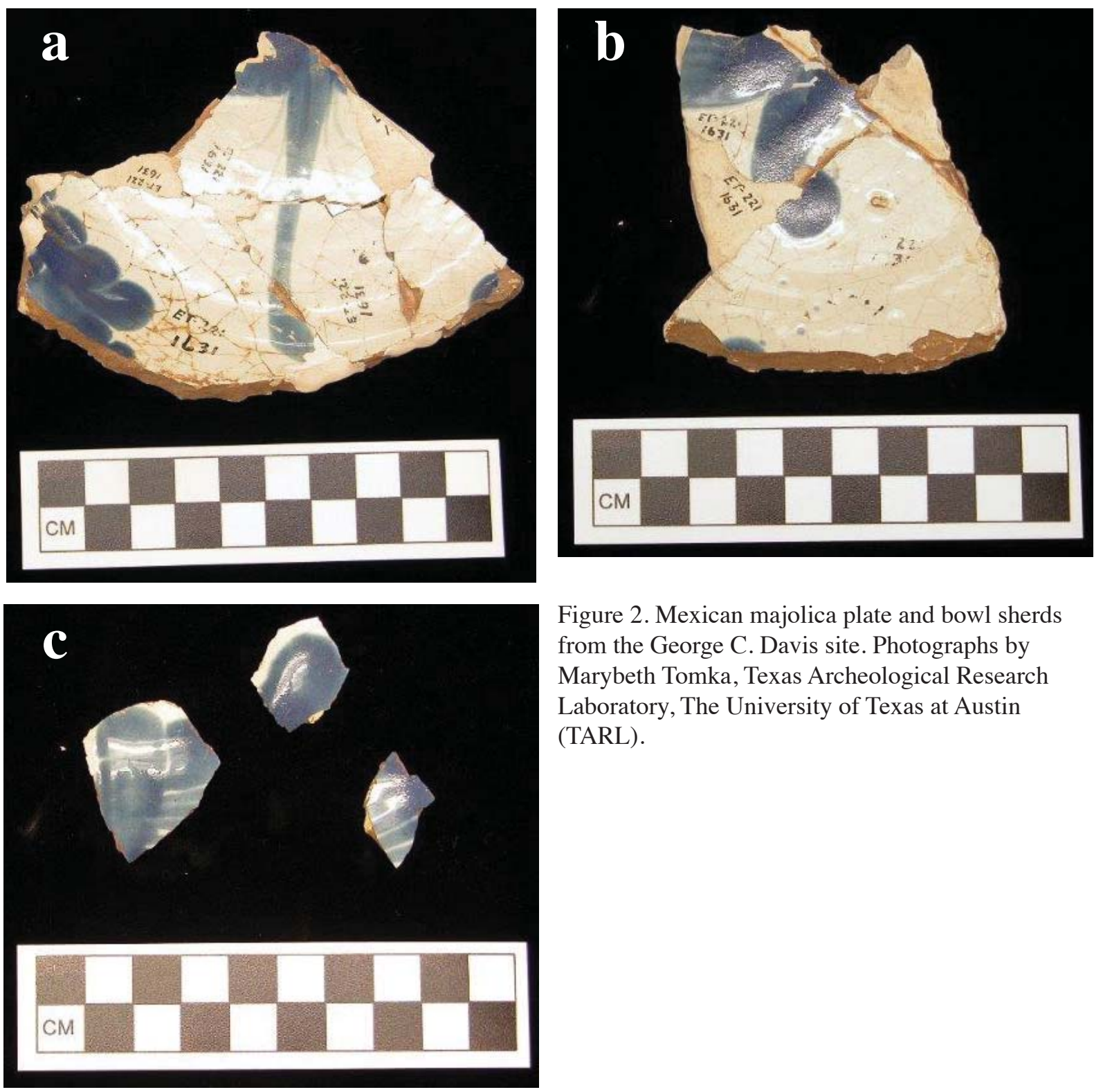

Figure 2. Mexican majolica plate and bowl sherds from the George C. Davis site. Photographs by Marybeth Tomka, Texas Archeological Research Laboratory, The University of Texas at Austin (TARL).

The majolica sherds are from two $10 \times 10 \mathrm{ft}$. units in the eastern part of the block (see Figure 4a). In 46L36, the one majolica sherd came from 1 inch below the surface (ca. $2.5 \mathrm{~cm} \mathrm{bs}$ ), according to the field specimen inventory records. The other sherds were recovered between 4-19 inches below the surface (ca. $10-48 \mathrm{~cm} \mathrm{bs}$ ) in 47L37, but most of the sherds and the largest pieces (see Figure 2a-b) were from 5 and 10 inches below the surface (ca. $13-25 \mathrm{~cm} \mathrm{bs}$ ).

Ancestral Caddo sherds were not abundant in these southern excavations, occurring at a mean density of 32.7 sherds per $10 \times 10 \mathrm{ft}$. unit. These sherds were most abundant in two units in the western part of the block excavations (see Figure 4b). According to the field specimen inventory records, ceramic sherds were recovered to depths of between 20-53 inches below the surface (ca. 51-134 cm bs). A total of 589 ceramic sherds were recovered in the block excavations.

Other artifacts noted in the field specimen inventory records from this block excavations included animal bone fragments $(n=20)$, charcoal pieces $(n=43)$, projectile points $(n=2)$, scrapers $(n=9)$, ground 


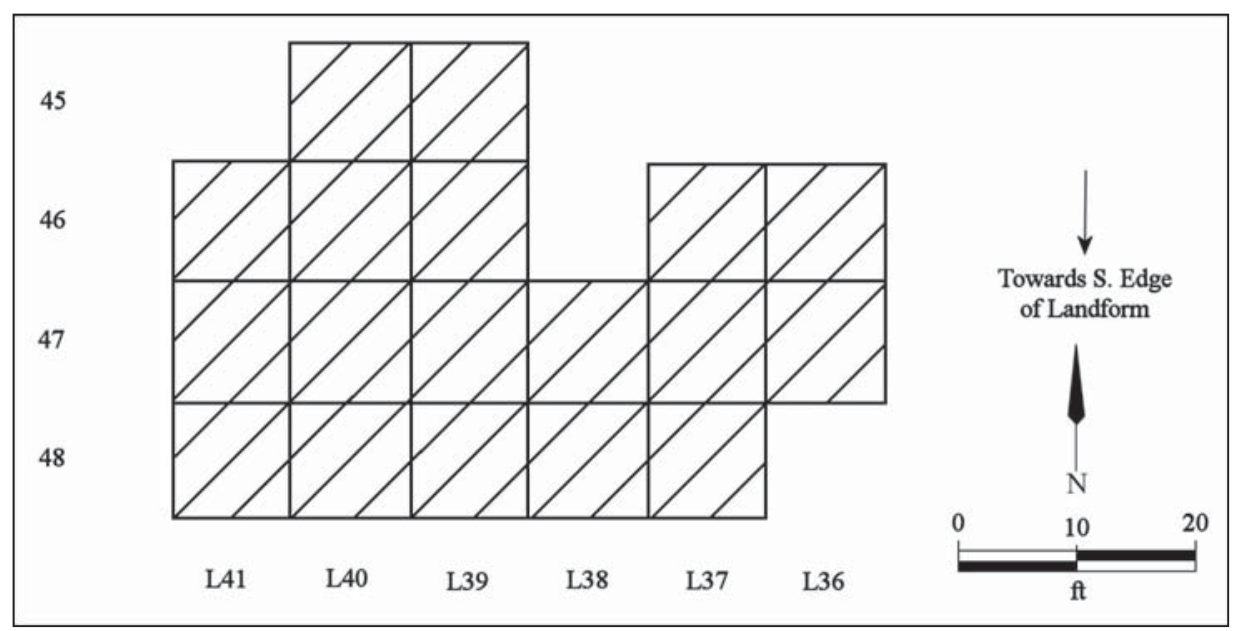

Figure 3. Excavation plan for Units between sections 45-48 and L36-41.

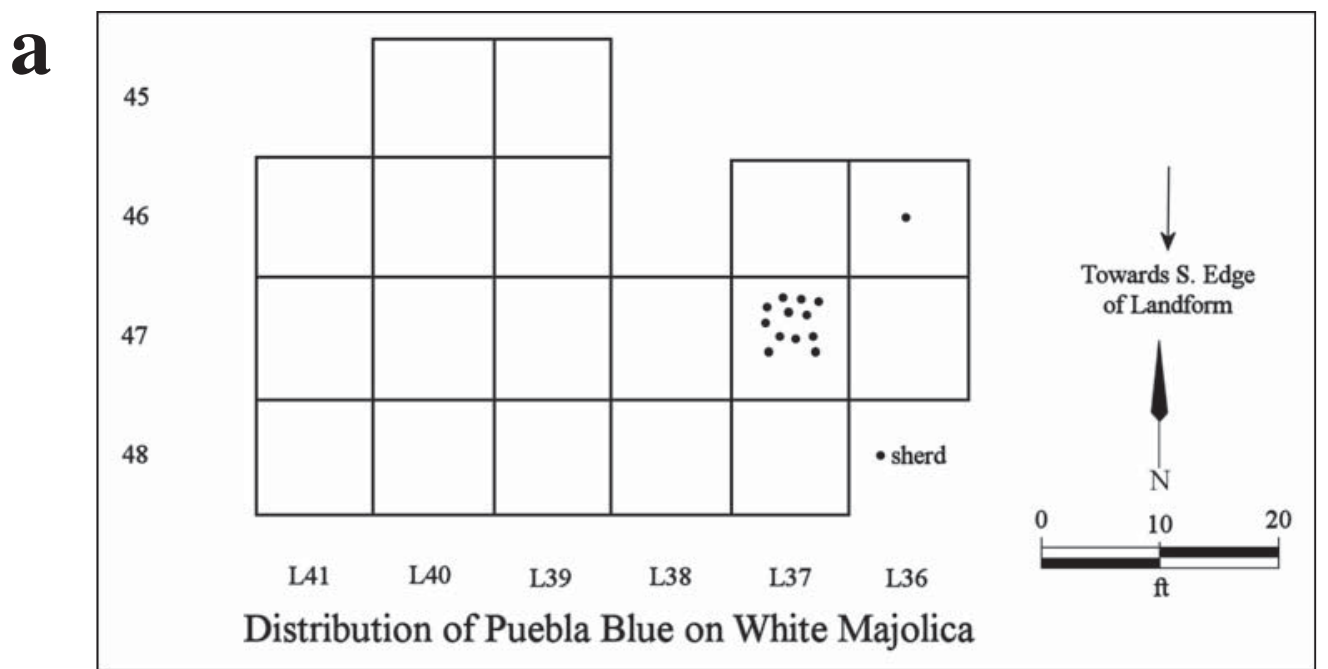

b

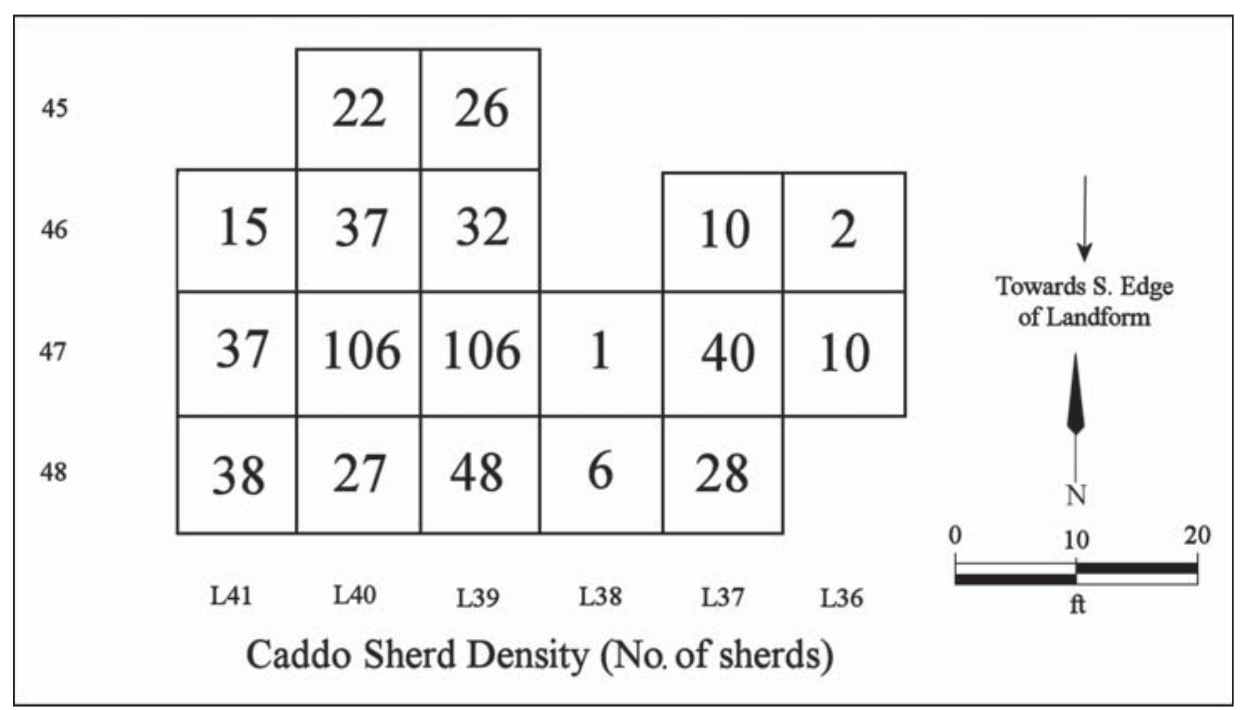

Figure 4. Distribution of artifact classes in the block excavations at the southern end of the George C. Davis site: a, distribution of Puebla Blue on white majolica sherds; b, distribution of Caddo ceramic vessel sherds. 
stone tools $(n=5)$, and fire-cracked rock $(n=2)$. None of these artifacts have been re-examined, and it is not known if any of these material culture remains are associated with the Puebla Blue on white majolica sherds from the block excavations.

\section{Conclusions}

The recovery of early $18^{\text {th }}$ century Mexican majolica sherds in one locale at the George C. Davis site indicates that there are preserved Spanish colonial archaeological deposits there; the overall extent and character of those deposits is not known at the present time. Available WPA records point to their recovery in a March 1940 block excavation along the southern end of a Neches River alluvial terrace, about 150-175 m south of Mound A, the large ancestral Caddo platform mound excavated between 19391941 at the site. Hopefully, in the future, the WPA collections from this southern block can be analyzed and documented in detail. Also, hopefully new field work can be conducted on this southern terrace to relocate and study the Spanish colonial deposits preserved there, and determine if these archaeological deposits are associated with the 1716-1719, 1721-1730 Mission San Francisco de Tejas/de los Nechas.

\section{Acknowledgements}

Thanks to Marybeth Tomka for relocating the majolica sherds in the vast collections from the George C. Davis site at TARL, and for taking the photographs of the majolica sherds used in this article.

\section{References Cited}

de la Teja, J. F. (editor)

1999 Wilderness Mission: Preliminary Studies of the Texas Catholic Historical Society II. Studies in Southwestern Catholic History No. 2. Texas Catholic Historical Society, Austin.

Foster, W. C.

1995 Spanish Expeditions into Texas, 1689-1768. University of Texas Press, Austin.

Fox, A. A. and K. M. Ulrich

2008 A Guide to Ceramics from Spanish Colonial Sites in Texas. Special Report No. 33. Center for Archaeological Research, The University of Texas at San Antonio.

Newell, H. P.

1940 Report for Second Quarter of 1940 on East Texas Crew No. 1 (Works Project No. 15312): Continuation of Work in Village and Mound. Report on file, Texas Archeological Research Laboratory, The University of Texas at Austin.

Newell, H. P and A. D. Krieger

1949 The George C. Davis Site, Cherokee County, Texas. Memoir No. 5. Society for American Archaeology, Menasha, Wisconsin.

Story, D. A.

2000 Introduction. In The George C. Davis Site, Cherokee County, Texas, by H. P. Newell and A. D. Krieger, pp. 1-31.2nd Edition. Society for American Archaeology, Washington, D.C.

Weddle, R. S., with contributions by J. H. Jarvis and D. G. Creel

2012 Archival and Archeological Research: Camino Real de los Tejas and Texas State Parks. Texas Parks and Wildlife Department, State Parks Division, Historic Sites and Structures Program, Austin. 